\title{
Creating the Competitive Edge:
}

\section{A New Relationship between Operations Management and Industrial Policy}

\author{
Martin Spring ${ }^{1}$, Alan Hughes ${ }^{2}$, Katy Mason ${ }^{3}$ and Paul McCaffrey ${ }^{4}$
}

1. Centre for Productivity and Efficiency, Lancaster University Management School, UK

2. Imperial College Business School, London, UK; Centre for Business Research, University of Cambridge, UK and Lancaster University Management School, UK

3. Lancaster University Management School, UK

4. UK Government, Department for International Trade 


\title{
Creating the Competitive Edge:
}

\section{A New Relationship between Operations Management and Industrial Policy}

\begin{abstract}
Policy interventions by governments to alter the structure of economic activity have either been dismissed or ignored by operations management (OM) scholars. However, in recent years, such 'industrial policy' measures have gained increasing support in developed economies, particularly in relation to manufacturing. This paper argues that contemporary manufacturing in high-cost economies is rooted in technological innovation. As such, it can be enhanced by industrial policy interventions that prevent systems failures in the process of turning technological innovation into commercially viable products. In particular, we argue that this can be achieved by establishing non-firm, intermediate research organizations and by other measures to change the institutional architecture of an economy. We disagree with claims in earlier OM literature that industrial policy is all but irrelevant to manufacturing firms and to OM. Instead, we argue that OM must broaden its conceptual scope so as to encompass active engagement with non-firm network participants such as governmentsupported intermediate research organizations, and that, as well as learning to be effective users of industrial policy, OM practitioners and academics should engage actively in the development of industrial policy. In this way, high-value, high-productivity manufacturing can be viable in high-cost economic environments.
\end{abstract}




\section{Creating the Competitive Edge:}

\section{A New Relationship between Operations Management and Industrial Policy}

\section{Introduction}

The offshoring of manufacturing has been a serious concern in developed economies in the past decade (Blinder, 2006; OECD, 2007; Harrison and McMillan, 2010) As a result, there has been growing support for policy interventions to reverse this trend, particularly since the 2007-8 global financial crisis. In the US, the Obama administration established the Advanced Manufacturing National Program Office (AMPSC, 2012). In the UK, the 2010-2015 Government developed an 'industrial strategy' to help rebalance the economy, away from financial services and back toward manufacturing: in the words of Peter Mandelson, the UK Secretary of State for Business from 2008 to 2010, "less financial engineering and a lot more real engineering" ${ }^{1}$. In 2016, the US Presidential Election and the UK's referendum on membership of the European Union have both made the global location of manufacturing and the idea of industrial strategy even more important in the political sphere.

Competitive threats from developing economies are, of course, nothing new. The rise of Japanese manufacturing during the 1970s was a particular cause for concern in the US and UK, and gave rise to a great deal of activity in operations management (OM) research on topics such as JIT, lean, quality management and supply management. Various forms of industrial policy responses were also developed. In this regard, senior operations managers and policy-makers have been concerned with many of the same phenomena: the changing nature of manufacturing processes, organizations, markets and supply networks, and the evolution of our understanding of them. Whereas thirty or forty years ago the primary unit of analysis for both policy and OM would have been firms and domestic sectors, both communities are now faced with understanding how to capture value from product and process innovation in complex, globally-dispersed manufacturing value chains (Hughes, 2012). Despite these many common concerns, however, there has been precious little dialogue between

\footnotetext{
${ }^{1}$ Labour Party Conference 2009 http://www.labour.org.uk/peter-mandelson-speech-conference
} 
industrial policy and the OM discipline. This paper seeks to establish such a dialogue, in order to understand how industrial policy and $\mathrm{OM}$ can be combined to enhance the competitiveness of manufacturing in high-cost economies, given the nature of contemporary manufacturing and the theoretical developments in both the $\mathrm{OM}$ and industrial policy spheres.

The paper is structured as follows. Since some of the concepts discussed are more typically encountered in economics and development studies, we begin by clarifying these. We define industrial policy and consider the relationship between the competitiveness of firms, which is the more typical concern of the management and OM literature, and the aggregate picture at the level of national economies. Three connected arguments are then developed. First, we examine the changing conceptualization of manufacturing in OM and manufacturing strategy since the 1980s, when manufacturing firms were trying to make sense of and develop strategic responses to the threat from Japanese manufacturing firms in particular. Second, over the same period, we summarize the main trends in the industrial policy implemented by successive governments in one particular developed economy, the UK. Third, we complement this account of actual industrial policy in a particular country by explaining the development of the more general underlying theoretical ideas on industrial policy, which have increasingly been informed by the approach known as 'systems-of-innovation' (Edquist, 1997). All three of these arguments reflect similar themes, notably the importance of considering more extended, fragmented and geographically-dispersed supply networks, and the central importance of innovation. The systems-of-innovation approach is thus an appropriate basis for a new understanding of industrial policy - in theory and practice - and for the new relationship between industrial policy and OM for which we argue. This broad shift in industrial policy thinking is then examined in concrete form by studying recent initiatives in the UK, including the establishment of intermediate research organizations known as 'Catapults'. Based on this examination, we identify new issues for OM, as well as arguing for a more OM-infused approach to policy.

Since we go on to examine some exemplar policy initiatives in the UK, it is also useful briefly to outline some of the specific economic context against which this policy is being considered, so that its relevance to other economies can be better understood. (More details on these aspects of the UK 
economy are presented in Appendix 1.) In summary, compared to other major developed economies, the UK manufacturing sector has been characterized by low growth and productivity, a lack of investment in capital equipment, and declining employment. Despite the world-leading performance of UK universities in basic sciences, UK manufacturing shows weak innovation performance, and an unusually high proportion of UK R\&D is funded and conducted by foreign-owned firms. Given this background, a prominent concern of UK industrial policy is to enable the academic excellence of the science and technology base to be translated into improved innovation and productivity performance in UK firms. This focus is another reason for the relevance of the systems-of-innovation approach.

\section{Key Concepts: Industrial Policy and Competitiveness}

It is important to clarify some of the concepts that are central to what follows. First, we outline key definitions of industrial policy, then we discuss the concept of competitiveness and its relationship to industrial policy and manufacturing.

\subsection{Industrial policy}

Industrial policy can be defined as follows:

"Industrial policy is any type of intervention or government policy that attempts to improve the business environment or to alter the structure of economic activity towards sectors, technologies or tasks that are expected to offer better prospects for economic growth or societal welfare than would occur in the absence of any such intervention ..." (Warwick, 2013: 16-17)

In a business and management context, notably at Harvard Business School, the term 'policy' has referred to business strategy (Bower, 1982; Bower et al., 1991). In operations management, Skinner (1969) is now known for developing the notion of manufacturing strategy, but typically referred to it as 'manufacturing policy', both in his 1969 HBR paper and in a series of industry casebooks (e.g. Skinner and Rogers, 1968). It is important to be clear that industrial policy is not business policy or 
manufacturing strategy: industrial policy is, as the definition states, an intervention by, or policy of, government.

A distinction is typically drawn between horizontal and sectoral (or vertical) industrial policy (Crafts and Hughes, 2013). Horizontal policy is intended to provide public goods that the market would otherwise under-provide, such as education, R\&D and training (Chang et al., 2013: 7) and not to target any firm, sector or locality more than any other. Sectoral industrial policy, in contrast, is deliberately targeted at some sectors and/or firms. A government might, for example, provide special support to firms in aerospace ${ }^{2}$. Targeting has been criticized on the grounds that governments are incapable of 'picking winners', for example by providing financial support to firms selected as 'national champions' in strategic sectors, an approach largely discredited since the 1970s. Critics also argue that targeted policies may be captured by firms, sectors and lobbyists to further their own ends or the ends of those they represent, rather than the wider economic constituency originally intended to benefit - so-called 'regulatory capture' (Chang et al., 2013: 8). Targeting is, however, difficult to avoid, since all but the most general horizontal policies (e.g. primary education) have implicit targeting (Chang et al., 2013). For example, policies to improve rail and seaport transportation infrastructure will favor manufacturers of relatively bulky goods; the provision of tax-breaks for R\&D will favor research-intensive industries. As Michael Porter puts it: 'Every nation practices implicit targeting of some kind, whether it will admit to it or not.....The issue, then, is less whether targeting is taking place than how a nation is going about it' (Porter, 1990: 673). Part of the concern of this paper is to understand how, despite these difficulties, industrial policy can be actively targeted.

\subsection{Industrial policy objectives and firm competitiveness}

We are concerned to understand how industrial policy can help manufacturing firms to be competitively located in developed economies, where costs, especially labor costs, are high. This is seen as an attractive policy objective, especially post-2008, because manufacturing has higher levels of innovation, productivity growth and export intensity than other sectors, which improves the balance

\footnotetext{
${ }^{2}$ In practice, however, the idea of sectoral policies is under increasing strain, as the boundaries of traditional sectors become blurred, manufacturing and services are combined, and information technology becomes increasingly pervasive and disruptive.
} 
of trade and provides economic resilience in the face of macro-economic shocks (Foresight, 2013). Manufacturing can also offer high-skill, highly paid jobs. For this to happen, manufacturing firms must compete more effectively, in markets for products and services, with firms located elsewhere.

The competitiveness of firms is stressed here, because such concerns have often been discussed in terms of 'competitiveness' at the national level' ${ }^{3}$ As Krugman (1994) has pointed out, however, countries do not compete with one another in the same way that firms do, even though this may be a superficially persuasive form of words as used by politicians and other commentators. Firms compete with firms, and the aggregate outcome of this process may lead to economic growth and increased social welfare in the domestic economy as a whole. Industrial policy ultimately seeks to achieve this through enhanced productivity, rather than through growth in individual firms, since the latter could be achieved by mergers without any addition to national GDP.

Developing industrial policy requires understanding a country's particular combination of social infrastructure and political institutions (Delgado et al., 2012; World Economic Forum, 2015) so as to effectively design and implement policies to enhance the productivity and competitiveness of its firms. The broad differences in the institutional context or 'institutional architecture' between countries, and hence the policy context, affect both corporate governance and management practice. They also influence the development of industrial structure and the promotion of the productivity and hence competitiveness of a nation's firms (Iversen and Soskice, 2010; Crafts and Hughes, 2013). Such differences have been examined in the 'varieties of capitalism' literature, which draws a broad, ideal-type distinction between 'liberal market economies' such as the US and UK and 'co-ordinated market economies' such as Japan and Germany (Hall and Soskice, 2001; Hall and Gingerich, 2009). This literature also argues that individual countries' institutional architectures vary on a spectrum between these two ideal types. These architectures may also change over time in the face, for example, of the globalization of some markets, the changing nature of competitive processes in

\footnotetext{
${ }^{3}$ Indeed, the title of Hayes and Wheelwright's book, 'Restoring Our Competitive Edge' (emphasis added), which is discussed later, suggests a concern with national competitiveness, as well as competitiveness at firm level.
} 
particular sectors, and the changing importance and international value chain connections between firms (Crafts and Hughes, 2013; Baldwin and Evenett, 2015).

\section{The changing manufacturing landscape: insights from the manufacturing strategy and $\mathrm{OM}$}

\section{literature}

Any analysis of the competitiveness of manufacturing and industrial policy must reflect on what manufacturing is, and how the answer to that question has evolved. The disconnect between $\mathrm{OM}$ and industrial policy can in some ways be traced back to the emergence of the manufacturing strategy field in OM, and Hayes and Wheelwright's Restoring Our Competitive Edge (1984) (hereafter ' $R C E$ ') in particular. Both of these were responses to an earlier version of the challenge facing today's developed, high-cost economies: the threat from developing countries' manufacturing sectors. $R C E$ was the most cited source in the OM discipline in the period 1980-2006 (Pilkington and Meredith, 2008) and, as well as defining the manufacturing strategy field, argued (as we shall see) that industrial policy was largely irrelevant to manufacturing management.

We suggest that, in the intervening thirty-plus years, the nature of manufacturing and its conceptualization in the OM literature has changed a great deal. In short, the change could be described as a shift from a closed, rational system to an open, socio-technical system. Compared to the 1980s, manufacturing is spatially dispersed, organizationally fragmented, and includes more of the total value chain. It is required to perform on parameters such as sustainability that were all but irrelevant in the 1980s. So, while rejection of industrial policy may have been an appropriate response in the 1980s, there is at least a prima facie case for reconsidering it in the light of the changes described, and for rethinking the unit of analysis around which policy might be formulated. Table 1 summarizes key changes. The following sections explain these further, beginning with a discussion of how the problem was framed in $R C E$, and how the role of industrial policy was discussed in this context. 


\begin{tabular}{|l|l|l|l|}
\hline & \multicolumn{1}{|c|}{ Early 1980s } & \multicolumn{1}{|c|}{ Mid 1990s } & \multicolumn{1}{|c|}{ 2000s } \\
\hline Activities included & Production & $\begin{array}{l}\text { Production, NPD and } \\
\text { (maybe) sourcing (Big } \\
\text { M) }\end{array}$ & $\begin{array}{l}\text { Whole value chain } \\
\text { from R\&D to service } \\
\text { and recycling }\end{array}$ \\
\hline $\begin{array}{l}\text { Theoretical } \\
\text { underpinning }\end{array}$ & $\begin{array}{l}\text { Process choice } \\
\text { /contingency } \\
\text { (Porter/Skinner) }\end{array}$ & $\begin{array}{l}\text { Capabilities in } \\
\text { production (AMSs and } \\
\text { RBV) }\end{array}$ & TCE, RBV, complexity \\
\hline Performance criteria & Quality, cost, delivery & $\begin{array}{l}\text { Add flexibility and } \\
\text { NPD }\end{array}$ & $\begin{array}{l}\text { Add sustainability, } \\
\text { risk, resilience }\end{array}$ \\
\hline Unit of analysis & Plant or firm & $\begin{array}{l}\text { Stable, limited supply } \\
\text { chain }\end{array}$ & $\begin{array}{l}\text { Fluid, extended } \\
\text { network }\end{array}$ \\
\hline $\begin{array}{l}\text { Geographical scope of } \\
\text { entities considered }\end{array}$ & $\begin{array}{l}\text { Domestic, unitary } \\
\text { facilities }\end{array}$ & $\begin{array}{l}\text { (maybe) 'foreign' } \\
\text { factories }\end{array}$ & $\begin{array}{l}\text { Global, IT-infused, } \\
\text { fragmented supply } \\
\text { networks }\end{array}$ \\
\hline
\end{tabular}

Table 1 - The changing conceptualization of manufacturing

\subsection{Hayes and Wheelwright's analysis of the 'new industrial competition' and government's role}

Many elements of Hayes and Wheelwright's analysis and argument endure: for example, the productprocess matrix and the distinction between structural and infrastructural decision areas. Much less discussed is the fact that almost a third of $R C E$ was devoted to (a) broader competitiveness issues in the US economy and (b) the distinctive manufacturing practices of then-successful manufacturing nations: Japan and Germany, collectively termed 'the new industrial competition' (Hayes and Wheelwright, 1984: 392). Hayes and Wheelwright argued that the response to this competition lay in 
the hands of management, rather than in those of policy-makers or in the forces of national culture, traditions or values. They presented this argument in a two-by-two matrix ${ }^{4}$, shown in Figure 1.

\begin{tabular}{|c|c|c|}
\hline & $\begin{array}{l}\text { Structure } \\
\text { ("hardware") }\end{array}$ & $\begin{array}{l}\text { Infrastructure } \\
\text { ("software") }\end{array}$ \\
\hline $\begin{array}{l}\text { Macro } \\
\text { (country) }\end{array}$ & $\begin{array}{l}1 \\
\text { Fiscal/tex policies } \\
\text { Monetery policies } \\
\text { Trede policies } \\
\text { Industrial policies } \\
\text { Copital merkets } \\
\text { Political structure } \\
\text { Orgenized lebor }\end{array}$ & $\begin{array}{l}2 \\
\text { Culture } \\
\text { Treditions } \\
\text { Religion } \\
\text { Velues } \\
\text { Social behevior }\end{array}$ \\
\hline $\begin{array}{l}\text { Micro } \\
\text { (firm) }\end{array}$ & $\begin{array}{l}3 \\
\text { Business and market } \\
\text { selection } \\
\text { Plant and capital decisions: } \\
\text { Copecity/facilities } \\
\text { Location/specialization } \\
\text { Process technology } \\
\text { Vertical integration }\end{array}$ & $\begin{array}{l}4 \\
\text { Messurement and control } \\
\text { systems } \\
\text { Workforce policies } \\
\text { Vendor relationships } \\
\text { Manegement selection and } \\
\text { development policies } \\
\text { Copital budgeting/ allocetion } \\
\text { decisions } \\
\text { Orgenization structure }\end{array}$ \\
\hline
\end{tabular}

Figure 1 - Key Elements of manufacturing competitiveness

(adapted from Hayes and Wheelwright 1984: 393)

The southwest box of Figure 1 (box 3) is at the heart of RCE: managers need to design the hardware of firm-level production processes to provide the necessary competitive performance priorities for their markets (the 'structural' decisions); box 4 contains the firm-level 'software' or infrastructural decision areas - introduced in $R C E$, but treated at greater length in Hayes et al. (1988). Many manufacturing firms across the developed economies have indeed adopted these types of firm-level strategies. The top two boxes are 'macro' perspectives: box 1 shows the 'hardware' of tax and fiscal policies, industrial policy and the like; box 2, macro 'software' of culture, traditions etc. Hayes and Wheelwright's view on these is clear:

"We do not believe that the first quadrant - macro/structure - is the dominant cause of most manufacturing companies' competitive problems....Companies who believe that their

\footnotetext{
${ }^{4}$ Originally due to Abernathy, W.J., Clark, K.B. and Kantrow, A.M. (1981) The new industrial competition. Harvard Business Review, 59, 5, 68-81., as is the term 'new industrial competition'
} 
salvation lies in actions taken in this quadrant, particularly those who operate in free market systems (such as the United States) are seriously misdirected, in our view" (Hayes and Wheelwright, 1984: 394).

As we shall see, governments in developed economies also seemed to agree that industrial policy was not important: for example, in 1989 in the UK, Conservative minister Nicholas Ridley, upon taking over as head of the then Department of Trade and Industry (DTI), famously asked "What is the DTI for? I've got bugger all [i.e. nothing at all] to do, and thousands of staff to help me do it." (Guthrie, 2004). Industrial policy has barely featured in the OM literature since RCE. We return to industrial policy later, but now discuss in more detail the changing conceptualization of manufacturing in $\mathrm{OM}^{5}$.

\subsection{Major changes in the conceptualization of manufacturing}

Manufacturing has progressively embraced the whole value-chain associated with products, including R\&D, new product development, sourcing, production, distribution, services, re-use, remanufacturing and recycling (e.g. Zhang and Gregory, 2011; Guide and Van Wassenhove, 2006; Baines et al., 2009; Foresight, 2013). In contrast, the work of Hayes, Wheelwright and colleagues up to the mid-1980s was essentially a way to think about the strategic management of production (i.e. material conversion and assembly) according to the firm's competitive priorities and the volume and variety of output (e.g. Hayes and Schmenner, 1978; Hayes and Wheelwright, 1979a; Hayes and Wheelwright, 1979b). Subsequent work (Hayes et al., 1988) emphasized the 'software' of production, influenced by Japanese firms' use of quality systems, JIT and so forth. In the early 1990s, again influenced by Japanese manufacturing, attention turned to new product development (NPD) (Wheelwright and Clark, 1992; Ettlie, 1995), typically seeing NPD as (a) needing to be better integrated with the production process and (b) itself a process that could be improved by OM approaches. Some termed this more inclusive view 'Big M manufacturing' (Hayes, 1992; Ulrich and Eppinger, 1992; Clark, 1996). More recently, in practice and in the OM literature, manufacturing increasingly incorporates aspects of service, such as design, maintenance, consultancy and customer

\footnotetext{
${ }^{5}$ Voss, C.A. (2005) Paradigms of manufacturing strategy re-visited. International Journal of Operations \& Production Management, 25, 12, 1223-1227. also presents a summary of some aspects of these changes.
} 
support (Neely, 2008). As such, it is extending not only upstream, as it did to some extent by incorporating NPD, but also downstream into the customer's operations (Wise and Baumgartner, 1999; Oliva and Kallenberg, 2003) - so-called 'servitization'. In these ways, 'Big M' manufacturing has gotten very much bigger and, from an industrial policy perspective, it is a different object of consideration to the manufacturing of the 1980s.

The theoretical underpinning of manufacturing strategy has moved from process choice to a resourcebased view, reflecting the growing importance of learning, innovation and idiosyncratic firm- and network-level capabilities. The work of Skinner $(1969 ; 1974)$ and Hayes and Wheelwright (1979b) was about fitting the firm- or plant-level production process to the market, in terms of a 'trade-off' between competitive priorities. In this sense, it broadly parallels Porter's (1980) approach (Voss, 1995) of choosing between cost and differentiation. Then, in the early 1990s, manufacturing strategy incorporated the resource-based view of the firm (Barney, 1991) and core competences (Prahalad and Hamel, 1990). This was most fully set out in a 1996 special issue of the POM Journal, where Hayes, Pisano, Clark, Wheelwright and others work through the implications of (a) 'Advanced Manufacturing Systems' (AMS - a collective term for JIT, TQM, SPC, etc.) and (b) resource-based perspectives (Hayes and Pisano, 1996; Clark, 1996; see also Hayes and Pisano, 1994). In short, tradeoff choices were still seen as relevant, but manufacturing performance was also based on underlying capabilities, both in the implementation of generic AMSs, and in specific technology domains (Mills et al., 2003). More recent work has continued on this trajectory, for example by showing the importance of manufacturing firms' 'intellectual capital' to performance (Menor et al., 2007).

The range of performance objectives considered in manufacturing strategy has broadened to include some criteria that were not even mentioned in the 1980s. The original performance objectives were quality, cost and delivery (Anderson et al., 1989), occasionally incorporating flexibility (Slack, 1987). As NPD became important, innovation speed was added (Stalk, 1988). Operations now are required to perform not only on these performance objectives, but also on dimensions such as sustainability (Carter and Easton, 2011; Pagell and Wu, 2009) supply risk (Zsidisin, 2003), and supply chain 
resilience (Ponomarov and Holcomb, 2009), which again call attention to the wider, socio-technical system.

The unit of analysis in manufacturing strategy has shifted from the plant or firm to the supply network, with supply chain management growing as a domain of OM research from the mid-1990s to the late 2000s (Pilkington and Meredith, 2008). Although 'vendor relations' had been discussed briefly in $R C E$, supply chain management subsequently came to encompass many issues, especially lean supply and supply relations (Womack et al., 1990; Lamming, 1993), supply chain design (Fisher, 1997), and the need for greater integration between firms (Frohlich and Westbrook, 2001). Operations are now seen by some as fundamentally inter-organizational (Buhman et al., 2005; Sinha and Van de Ven, 2005; Hayes, 2008). Furthermore, whereas plant-level manufacturing strategy approaches and, to some extent, supply chain management sought to design and control the whole system directly, fragmented networks are perhaps better understood as complex adaptive systems in which any one firm has only local and partial control (Choi et al., 2001). Miles et al. (2010) suggest that the emerging organizational form for the $21^{\text {st }}$ century, rather than the multi-firm network, is the 'collaborative community'. As such, the 'institutional architecture' in which such adaptive systems and communities operate becomes an increasingly important ingredient in manufacturing firms' business landscape.

As well as becoming more fragmented in structure, the geographical scope of manufacturing strategy has increased. In recent years globally-dispersed manufacturing and offshoring have been dominant features of the world economy (UNCTAD, 2013). Despite this, there has been a relatively limited treatment within OM of international production (Fuchs and Kirchain, 2010), with a few notable exceptions (Ferdows, 1997; Shi and Gregory, 1998; Zhang and Gregory, 2011; Naor et al., 2010). Taken together with the organizational fragmentation just discussed, this is characterized by Baldwin and Evenett (2012) as 'the second unbundling'. In the 'first unbundling' in the late $19^{\text {th }}$ century, railways and steamships allowed the spatial separation of production and consumption, leading to comparative advantage and economies of scale. In the 'second unbundling' (now), advances in ICT (information and communications technology) have made it technically possible to coordinate 
knowledge-intensive and complex activities at a distance, and between organizations: as Baldwin and Evenett put it, "ICT made it possible, wage differences made it profitable" (Baldwin and Evenett, 2012: 74).

Taken together, these broad changes mean that what we call 'manufacturing' now is a very different beast to the one considered by Hayes, Wheelwright and many others in the 1980s. Getting plant- and firm-level production processes right - i.e. aligned with a segment's competitive priorities - was a desirable step forward then; but now, it is only a small part of the challenge facing manufacturing managers.

\section{Changing approaches to industrial policy: the case of the United Kingdom}

Over this same period, attitudes in developed economies toward industrial policy have also changed a great deal (Foreman-Peck and Federico, 1999; Chang et al., 2013). Particularly during the period 2008-2015, the US and UK governments (amongst others) have made major, explicit policy interventions, many intended to revitalize manufacturing. In the case of the UK, which we examine here, three main themes are evident. First, policies have become more targeted on certain sectors and technologies, particularly since 2010 . Second, a number of regionally-focused initiatives have been taken. Finally, there has been a gradual increase in the emphasis on innovation, with innovation policy and more conventional industrial policy becoming increasingly indistinguishable. This latter convergence has occurred in several developed countries, including the US (O'Sullivan et al., 2013; Chang et al., 2013).

Table 2 summarizes these UK industrial policy changes over the period of interest. These are examined in more detail in the following sections, which use secondary data from various sources, including policy documents known as White Papers. 


\begin{tabular}{|c|c|c|c|}
\hline & $1980 \mathrm{~s}$ & 1990s & 2010-2015 \\
\hline $\begin{array}{l}\text { Overall } \\
\text { emphasis }\end{array}$ & $\begin{array}{l}\text { Deregulation and } \\
\text { privatization }\end{array}$ & $\begin{array}{l}\text { 'Competiveness' agenda, } \\
\text { continued deregulation, } \\
\text { with some horizontal } \\
\text { policies }\end{array}$ & $\begin{array}{l}\text { Stronger sectoral } \\
\text { emphasis, incorporating } \\
\text { strategies for emerging } \\
\text { technologies }\end{array}$ \\
\hline Horizontal & $\begin{array}{l}\text { Massive reduction in } \\
\text { selective and horizontal } \\
\text { policy support; } \\
\text { Emergence of Enterprise } \\
\text { Policy focused on SMEs } \\
\text { (small and medium-sized } \\
\text { enterprises), 'reducing } \\
\text { red tape', subsidizing } \\
\text { skills training, providing } \\
\text { loan support schemes and } \\
\text { grants for R\&D }\end{array}$ & $\begin{array}{l}\text { Enterprise Policy } \\
\text { continued }\end{array}$ & $\begin{array}{l}\text { Enterprise Policy } \\
\text { continued; } \\
\text { Additional focus on skills } \\
\text { development, access to } \\
\text { finance, supply chain } \\
\text { development and public } \\
\text { procurement of R\&D }\end{array}$ \\
\hline $\begin{array}{l}\text { Sectoral/ } \\
\text { Technology }\end{array}$ & & $\begin{array}{l}\text { Recognition of sectoral } \\
\text { and technology } \\
\text { differences; } \\
\text { Tax breaks to support } \\
\text { R\&D and investment in } \\
\text { hi-tech SMEs }\end{array}$ & $\begin{array}{l}\text { Stronger sector focus and } \\
\text { 'spectrum' of support } \\
\text { depending on sector } \\
\text { characteristics; } \\
\text { Identification and funding } \\
\text { of key general purpose } \\
\text { technologies (so-called ' } 8 \\
\text { great' technologies) }\end{array}$ \\
\hline Regional & $\begin{array}{l}\text { Retreat from regional } \\
\text { policy; } \\
\text { Reduction in subsidies to } \\
\text { support regional } \\
\text { redistribution of firms }\end{array}$ & $\begin{array}{l}\text { 'Clusters' prominent in } \\
\text { later 1990s; } \\
\text { Regional Development } \\
\text { Agencies (RDAs) } \\
\text { established }\end{array}$ & $\begin{array}{l}\text { Scrapping of RDAs, focus } \\
\text { on cities and local } \\
\text { enterprise partnerships } \\
\text { (LEPs); } \\
\text { Regional Growth Fund as } \\
\text { part of central government } \\
\text { policy }\end{array}$ \\
\hline Innovation & & $\begin{array}{l}\text { Shift toward innovation } \\
\text { /knowledge focus in later } \\
\text { 1990; } \\
\text { Enhanced university - } \\
\text { business links }\end{array}$ & $\begin{array}{l}\text { Innovation policy; } \\
\text { Establishment of } \\
\text { Innovate-UK agency with } \\
\text { increased selective focus; } \\
\text { Industrial activism } \\
\text { followed by industrial } \\
\text { strategy; } \\
\text { 'Catapult Centres' } \\
\text { established }\end{array}$ \\
\hline
\end{tabular}

Table 2 UK Industrial Policy 1980-2015 


\subsection{The early 1980s: deregulation and enterprise}

Margaret Thatcher's Conservative administration came to power in the UK in 1979. Industrial policy was revised (Crafts and Hughes, 2013): selectivity was abandoned and horizontal support cut back. Industrial subsidies had been $£ 8.9$ bn in $1970 / 71$; they fell to $£ 0.4$ bn by $1987 / 8$ (all figures at constant price value in 1980 prices). State aid for manufacturing fell from around 4\% of GDP in the 1980s to less than $1 \%$ by the mid-nineties. The emphasis was instead on competition policy, privatization, EUrelated reductions in trade barriers and the promotion of small business enterprise. The 1988 White Paper of the Department for Trade and Industry (DTI) was almost entirely devoted to 'creating a climate that stimulates enterprise and reduces red tape' (DTI, 1988: ii); it explicitly excluded the possibility of sectoral policies. The Conservative administration published three more White Papers on 'Competitiveness' between 1994 and 1996, all of which continued to focus policy on SMEs. This included a wide range of labour market, capital market and fiscal policy incentives to support small businesses, including training subsidies, and tax breaks to encourage investment in and lending to smaller businesses. It has been estimated that SME support was costing nearly £8bn by the early 2000s, as 'enterprise' policy replaced industrial policy (Hughes, 2010) .

\subsection{Clusters and regions}

Regions and localized 'clusters' around specific industries received support later in the 1990s, with Regional Development Agencies (RDAs) established in 1998. According to one analysis (BIS, 2010), RDAs were intended to reduce or eliminate regional differences in growth, but failed because of deep rooted problems of an overdependence on relatively slow-growth sectors and powerful agglomeration and location effects drawing economic activity to London and the South East of England in particular. RDAs were abolished in 2012, to be replaced by 'Local Enterprise Partnerships' (LEPs) with muchreduced funding. Further limited funding from the 'Regional Growth Fund' was provided from 2010 onwards. 


\subsection{A growing emphasis on sectors and technologies}

The policies in the 1995 White Paper (DTI, 1995) were still mainly focused on horizontal, enterpriseenhancing measures, including a prominent role for 'spreading best practice', notably including those that occupied OM academics at that time: supplier partnerships, improved approaches to new product development, and aspects of 'World Class Manufacturing'. However, although there were no 'sectoral policies' as such, there was some recognition of a sectoral perspective. The White Paper began by taking a sectoral view of performance. In innovation, a parallel initiative on Science, Engineering and Technology, known as 'Technology Foresight', brought together industry, academia and government to identify technology priorities across fifteen sectors. Then, the 1996 paper more explicitly discussed 'sectoral partnerships' and the need to accommodate sectoral differences: 'The detailed knowledge of individual sectors which the Government builds up through its sponsorship work allows it to react effectively to problems experienced by individual companies as well as to sector-wide issues' (DTI, 1996: 137). Nevertheless, governments continued to eschew selective sectoral policies: even in 2006, over $90 \%$ of government support for industry was devoted to horizontal policies (Buigues and Sekkat, 2011).

Only in the wake of the global financial crisis was a more sectoral approach adopted (Crafts and Hughes, 2013). In 2009, the New Industry, New Jobs paper (DBERR, 2009) argued for a 'new activism' in industrial policy, and presented a more sectoral approach. This was continued by the incoming government in 2010 and led to the explicitly sector-based 2013 'Industrial Strategy'. Horizontal policies continued: for example, making access to finance easier, and removing obstacles to setting up new businesses, in line with the World Bank's 'Doing Business' evaluation metric (World Bank, 2014). But effort and resources have been explicitly targeted on eleven areas, most of which are recognizable industrial sectors (e.g. aerospace, construction), some of which are rooted in fundamental science (e.g. life sciences) and at least one that is more pervasive: information economy. Some sectors (e.g. automotive) fit squarely on pre-existing, often mature institutional architectures, and the task has been to invest in making the institutions serve contemporary purposes. Others are newer and sometimes amount to constructing a nascent sector - an example here is the 'agri-tech' 
sector, which is part of the Life Sciences sectoral strategy. Horizontal policies are supplemented by sectoral intervention in a 'spectrum of support' (BIS, 2012: 30), ranging from 'light touch' to 'strategic partnership', depending on the nature of the sector. In some cases, sector councils have been established. These promote consultation between industry and government, in keeping with the philosophy of 'partnership', and allow discussion of the sector-specific implications of horizontal policies, as well as the development and shaping of sectoral policies. They are chaired by senior ministers and consist of representatives from firms in the sector, as well as Director-level government officials.

\subsection{The incorporation of innovation policy}

The White Paper of 1998, under the then newly-elected Labour administration, continued the competitiveness theme of its forerunners, but also captured the growing importance of the links between innovation, productivity and the science base, as demonstrated by its title: 'Our competitive future: building the knowledge-driven economy' (DTI, 1998). Innovation was the central issue, and deregulation a minor one - in contrast to previous White Papers. Subsequently, innovation policy was the dominant theme in a succession of White Papers and Policy Reviews (DTI, 2003a; DIUS, 2008; BIS, 2011). These reinforced the focus on networking and the development of cluster policy (DTI, 2003b) and the link between business and the science base (HM Treasury, 2003; 2004; Hughes, 2015). The analysis was increasingly couched in terms of system thinking and accompanied by horizontal support in the form of grants and subsidies for $R \& D$. R\&D tax credits for small firms were introduced in 2000 and extended to large firms in 2004. Innovation policy was rationalized, and delivery focused in 2007 around a new non-departmental agency, the Technology Strategy Board (TSB) (subsequently renamed Innovate-UK in 2014). Its programs initially included the Collaborative Grant for R\&D (linking large and small firms and the science base), Knowledge Transfer Partnerships (linking SMEs and Higher Education Institutions (HEIs) through co-funded postgraduate placements), and Knowledge Transfer Networks (linking businesses in a sector). TSB programs and initiatives frequently focus on particular sectors (e.g. automotive, aerospace) or technologies (e.g. bio- 
technology or nano-technology). Additional BIS funding was also announced for the so-called 'eight great technologies' (Willetts, 2013).

Most recently, the then-named TSB began delivering the Small Business Research Initiative (SBRI) Program, modeled on the US SBIR (Small Business Innovation Research) program to use public sector procurement of $\mathrm{R} \& \mathrm{D}$ to support high-tech SMEs, and the 'Catapult' program to foster university-business collaboration around a selected set of themes, sectors and technologies (TSB, 2011; Hauser, 2010). We examine the latter initiative later in this paper.

\section{The theoretical case for new approaches to Industrial Policy ${ }^{6}$}

The gradual shift toward more active and explicitly-targeted industrial policy (Chang et al., 2013), outlined here in the case of the UK, has been informed by new conceptualizations of the economic and organizational processes of innovation and production. These have allowed policymakers to address the changing nature of manufacturing and the intensified globalization of value and supply chains (Hughes, 2012; Greenaway, 2012). The 'systems-of-innovation' approach (Edquist, 1997) has been an important part of this conceptual shift, and has underpinned policies that seek to adjust the 'institutional architecture' of developed economies, so as to enhance interaction and learning, and hence promote the translation of innovation into productive industrial activity.

\subsection{Systems of Innovation}

As innovation has become a more important part of manufacturing, industrial policy is increasingly inseparable from innovation policy, as we have shown in the case of the UK. In the past, innovation policy has typically been intended to overcome 'market failure' in the production of research and development $(R \& D)$ activities. $R \& D$ knowledge is non-rivalrous in use: use by one firm does not reduce its availability for use by other firms. The market-failure argument is that motivation to invest in costly and highly uncertain R\&D activities will be reduced because the benefits of a firm's R\&D

\footnotetext{
${ }^{6}$ This section draws inter alia on Crafts and Hughes (2013), where a fuller discussion of the key arguments may be found.
} 
expenditure spill over to other producers and users. Industrial policy informed by this logic seeks to mimic the 'perfect' market outcome by creating legal rights to charge for access (e.g. patents), to subsidize knowledge production in the private sector (e.g. R\&D tax credits), or to carry it out in the public sector (e.g. through higher education institutions) and then grant free access.

Such policies, however, still don't entirely solve the problem of translating new technologies into productive industrial activity. Innovation - and, therefore, large parts of manufacturing industry depends on interaction between both private and public sector agents, occurs in a context of extreme uncertainty, and must be co-ordinated through a wide range of collaborative and network pathways. Because of this complex, interactive character, it cannot be managed as simply a linear process of R\&D 'push' governed by market mechanisms. Consequently, the market failure view has been supplanted by the systems-of-innovation approach, and the associated notion of systems failure. The concept of systems failure focuses on inhibitors to evolutionary change. These include problems of co-ordination or connection between innovation system elements such as firms, universities and other organizations. Systems failures include 'institutional' failure arising from conflicting motivations, norms and standards of behavior such as those between the academic and business spheres; and lockin failures arising from past investment decisions that limit business adaptability and adjustment. Policy interventions based on the systems-of-innovation approach seek to overcome shortcomings in the opportunities for interaction, in the institutions within which innovation takes place and in the evolutionary processes that promote variation and selection (Klein Woolthuis et al., 2005). In this sense, it is not market failure that is the problem, but market creation (Dodgson et al., 2011). Market failures still occur, but they are only part of the story.

Overcoming systems failure requires the creation and development of an appropriate institutional architecture' (Crafts and Hughes, 2013): a central assumption in the systems of innovation approach is that public and private sector agents interact in ways that go beyond arms-length, market relationships, and that these interactions are mediated by the institutional 'rules of the game', both formal and informal (North, 1990). These may, as the varieties-of-capitalism approach has emphasized, vary significantly across countries and time. Edquist and Johnson (1997: 51; 53-54) 
argue that institutions perform the following functions: reducing uncertainty through the provision of information; managing conflicts and cooperation, incentivizing certain activities, and channeling resources to innovation. Berger et al.'s recent major study of US manufacturing identifies a similar set of functions: convening, coordination, risk-pooling and risk-reduction, and bridging (Berger, 2013: 21). As such, innovation policy - and hence industrial policy - in such a context must 'centre on assisting the development and the evolution of the underlying knowledge structure that generates operational outcomes in a market, and not in the operational outcomes themselves' (Bleda and Del Rio, 2013: 1050).

Systems of innovation are often distinguished by an emphasis either on particular technologies, or particular sectors. A technological system may be defined as:

"a network or networks of agents interacting in a specific technology area under a particular institutional infrastructure to generate, diffuse and utilize technology. Technological systems are defined in terms of knowledge or competence flows rather than flows of ordinary goods and services." (Carlsson and Jacobsson, 1997: 268)

This emphasis on competence means that selective industrial policy must take account of how changes in technological systems affect particular elements of the value chains in which the firms are operating. Technological system failures are frequently associated with lock-in and sunk-cost problems. Such existing systems may continue to yield substantial value over many years, while new systems may not begin to generate a return until several years have elapsed. The policy challenge here is to achieve a balance in emphasis between the existing and the new, under circumstances where private capital markets may not be patient enough to tolerate long delays on returns.

A sectoral system of innovation, in contrast, is defined as:

"a set of new and established products for specific uses, and a set of agents carrying out activities and market and non-market interactions for the creation, production and sale of those products. A sectoral system has a knowledge base, technologies, inputs and (existing and potential) demand.” (Malerba, 2004: 16) 
Although the precise distinction between technological systems and sectoral systems is sometimes blurred, it will be evident that sectoral systems are in many ways closer to the end customer and are likely to involve multiple technologies, of varying degrees of novelty. The sectors, in this view, are not defined externally based on SIC codes or similar, but are the de facto systems of agents (firms and non-firm agents such as universities or trade associations) concerned with a particular set of products. As such, sectoral systems are likely to transform, and new sectors may emerge. They are less subject to lock-in problems, but often comprise agents with a greater diversity of priorities and norms.

\subsection{Implications for industrial policy}

Interaction and learning between agents is, as discussed above, a central theme of the systems-ofinnovation approach. Innovation is, after all, about learning. That being the case, while it is widely accepted that policy-makers are not sufficiently knowledgeable to 'pick winners', they do not have a monopoly on ignorance. Hence, Rodrik (2008) argues that industrial policy should be about enabling, facilitating and supporting learning and discovery among all the participants. He identifies three key issues. First, industrial policy needs to be built upon a detailed understanding of possibilities and prospects. Rather than operating top down to resolve market failures, the industrial policy is embedded in the knowledge flows and information typically found in the private-sector domain. Rodrik observes:

"the information that needs to flow from the private sector to the government in order to make the appropriate decisions on [industrial policy is] multi-dimensional and cannot be communicated transparently by a firm's actions alone. A thicker bandwidth is needed." (Rodrik, 2008: 26).

Second, because it is inevitable that some innovations will fail, policy must be built around an options approach. Initiatives must be regularly reviewed and support adjusted appropriately. Third, policy and its time frame must be built to ensure transparency and accountability to avoid uncertainty on the part of key agents, which could otherwise yield initiatives that are ultimately ineffective and short-term. Transparent evaluation of policy also guards against regulatory capture. Similarly, Kuznetsov and Sabel (2011) argue that 'new' industrial policy sees a shift from 'one-time choice of winners... to the 
process of error detection and error correction of the choices.' (Kuznetsov and Sabel, 2011: 1, emphasis in original).

In sum, these developments in thinking about systems of innovation, and about the nature and process of industrial policy, mean that there is a role for government in helping to resolve system failures by changing the institutional architecture associated with particular technologies and sectors. This is, as we have seen, quite different from the notion of governments 'picking winners' in the sense of subsidizing selected firms or sectors, come what may: as Rosenfield puts it:

"The challenge for policymakers is to foster an environment of innovation, and a strategy for firms is to develop competitive advantages in manufacturing that are linked to innovation" (Rosenfield, 2014: 212).

\section{Industrial Policy in Action in the UK - Innovate UK and Catapults}

We now examine a specific initiative within the UK Industrial Strategy, the High Value Manufacturing (HVM) Catapult. We seek to understand, in the theoretical terms outlined in the previous section, how the Catapult helps to alter the institutional architecture to make it possible for UK manufacturing firms to be more competitive. Such initiatives are underway in a variety of developed and developing economies (see for example Mina et al. (2009), Hauser (2010), Wessner and Wolff (2012)). Both secondary and primary research was used. A wide range of government and other documents were accessed from the public domain, complemented by prior research conducted by the authors as part of the UK Government's Foresight study, 'The Future of Manufacturing' (Foresight, 2013). Additionally, key informants were interviewed, including the CEO and Operations Director of the Catapult, and senior managers from a major aerospace firm working with it. 


\subsection{Innovate UK and Catapult Centres}

Innovate UK (formerly the Technology Strategy Board) is the main implementation vehicle for the Department for Business, Innovation and Skills (BIS) (see section 4.4). It operates at arm's length from BIS and has a budget of approximately $£ 400$ million. The majority of staff members have a business background. Innovate UK operates several schemes intended to stimulate innovation by bridging basic technological discovery (supported by universities and government research funding) and commercialization (funded by businesses). The schemes typically involve collaboration between universities and industrial partners, funded by government, by industry itself and perhaps by UK or European research councils. Projects to be funded are selected by a competitive process.

The Catapult program was initiated following a UK Government report by the entrepreneur Hermann Hauser (Hauser, 2010), and established seven Catapults, covering a range of technologies. Catapults are an example of what Mina et al. (2009) call 'intermediate research organizations' in that they sit between commercial firms conducting private research and universities carrying out publicly-funded research. After other firms such as suppliers and customers, businesses see intermediate research organizations as the most important external sources of knowledge related to innovation (Hughes, 2008). A 2008 study estimated that such organizations accounted for around one third of UK expenditure on R\&D conducted outside the firm: $80 \%$ of the firms surveyed reported that they 'could not have achieved the same results by just working in-house or with a university' (Oxford Economics, 2008).

\section{2 The High Value Manufacturing Catapult: structure, operation and insights}

We now consider the HVM Catapult. It comprises seven research centers, all in dedicated buildings, each specializing in a particular production technology such as metal-forming or composites. The HVM Catapult receives government funding of around $£ 25$ million per year (TSB, 2012) to employ staff and buy and operate specialist equipment. It generates income from businesses, both from membership fees and from payment for individual projects and, in competitive processes, from UK and European funding councils. Between April 2013 and April 2014, the HVM Catapult carried out 
914 projects, involving 1263 private sector clients, generating $40 \%$ of its income from industry sources and employing over 1200 engineers, technicians and support staff. For every $£ 1$ of core funding received from government, the HVM Catapult secured $£ 3.90$ of industry and collaborative funding.

We interviewed senior managers of a major aerospace firm ('AeroCo') involved in the HVM Catapult, in particular discussing the Advanced Manufacturing Research Centre (AMRC), one of the seven HVM Centres. AeroCo is one of 22 Tier 1 AMRC members, who each pay $£ 200000$ per year; 90 Tier 2 members pay $£ 30000$ per year. Members collectively develop ‘technology roadmaps’ to identify technologies of common concern, and agree a portfolio of core projects, as well as being able to commission individual projects to solve immediate or specific problems. According to our interviewees, firms such as AeroCo provide "a big demand signal" as to which projects are pursued. Tier 1 members have a seat on the board, access to results of all core research projects, and can shape the agenda for future research. Tier 2 members also have access to results of all core research projects, and collective board representation. Our interviewees from AeroCo estimate that about half of the company's manufacturing process $R \& D$ is conducted in the Catapult: this is not a marginal activity for them. The projects described to us consisted of using machines like those used in production, but with much greater instrumentation, enabling very thorough trials to be conducted. The aim of this kind of project is to refine a new process so that it can confidently be implemented in full-scale production, thereby reducing risk: as Bohn would put it, turning art into science (Bohn, 2005).

AeroCo organize relatively senior managers and technical staff into task-focused 'embedded teams' or 'Integrated Project Teams' in the Centre. The interviewees likened managing the team-working process to "marriage counselling", stressing the importance of ongoing, informal relationships, especially when collaborating with firms who were not direct production supply-chain counterparts, such as equipment vendors, software firms and tooling providers. Active involvement was stressed, with comments that it is no good simply to "pay someone to do the job" (i.e. develop the technology); rather, those who work in the Centre often return to an AeroCo production plant to implement the technology once it is stabilized. The embeddedness also extends beyond the walls of the Centre: we 
were told that on a given day, typically up to a third of staff would be offsite, visiting other collaborators - e.g. suppliers or other universities - on their premises.

It has taken years to develop this way of working. Other firms, less experienced with this approach, ask AeroCo how they are able to get so much benefit from the Catapult. Asked what their advice would be to firms engaging for the first time, one of our interviewees emphasized the need to visit both ways - to "kick the tires", and make sure it is the right Centre for the task in hand; second, to start with small, short-term projects; and third, to be actively involved rather than "sending a request and waiting for the answer to come back". As at the higher level, with sector councils, it seems that the keys to working with Catapults are also interaction and learning.

\subsection{Specific forms and functions of the UK institutional architecture}

Sectoral strategies and Catapults in UK industrial policy are concrete examples of deliberate changes in institutional architecture. Having outlined them, we now examine them in terms of the systems-ofinnovation approach. The discussion is structured in terms of the institutional functions proposed by Edquist and Johnson (1997), described in section 5.1.

The first of these functions is the reduction of uncertainty through the provision of information. Catapults have brought together existing and new resources within coherent and readily-identifiable organizational structures. As a result, firms can more easily find the resources they need, without having to research, say, individual university departments one by one. The development of strategies and technology roadmaps by Sector Councils and Catapult technical boards reduces uncertainty for firms working in contexts where technologies are complex and changing rapidly. Learning to be an active participant in shaping the future paths is as important an outcome as the roadmap itself.

The second function is the management of conflicts and cooperation. Catapults allow universities and firms to co-operate or collaborate effectively, and such collaboration is a critical part of the Catapult model. They bring together entities who are positively disposed toward collaboration in principle, but 
who previously found it difficult to connect at all in practice - what Berger (2013) calls the 'convening' role. The buildings housing Catapults are neutral territory and have institutions or 'rules of the game', such as cultures, conventions and membership structures with defined rights, that allow sometime-competitors to work together on projects of common interest. This allows entities to work together who previously would have actively avoided collaboration due to concerns about commercial rivalry or free-riding.

The next function is incentivization. Catapults are underpinned by government funding. In this sense, they provide firms with financial incentives to access resources that they could otherwise not afford on their own. In the HVM Catapult, the core funding allows the creation and maintenance of capabilities and facilities of a standard, scale and intensity that would be otherwise unfeasible for any single firm. Through successive projects, both the Catapult's individual Centres and the firms participating in them develop their capabilities, making subsequent projects likely to be even more productive. Participating in a Catapult also facilitates applying for further research-oriented funding from UK and European funding councils.

The final function is the channeling of resources to innovation. Catapults achieve this at multiple levels. First, by their very existence, they direct funding toward innovation. Second, because they are targeted, they direct this funding at some sectors and technologies rather than others. Third, participating firms are encouraged to direct their resources toward particular innovation activities, because the rules of membership and the risk-reducing effect of collective effort make it attractive to do so. This in turn makes it more likely that firms will commercialize technologies that might otherwise have been left unrealized.

In these ways, Catapults can indeed be seen as interventions that change the institutional architecture in which UK firms, universities and other organizations operate. In the HVM Catapult and in others, government is playing a 'convening' role (Berger, 2013), bringing together private sector and public organizations in dedicated locations with institutional 'rules of the game' intended to promote interaction and learning. The HVM Catapult's focus on high-value manufacturing cuts across 
traditional sectors and concentrates effort on the systems of innovation surrounding particular advanced processes and technologies.

\section{Discussion: the potential of industrial policy and implications for operations management}

Having examined the specific case of the UK in terms of the changes to institutional architecture, we now return to our starting point: Hayes and Wheelwright's conceptualization of the relationship between industrial policy and operations management. We reflect on their claim that industrial policy is insignificant in shaping firm competitiveness, and the associated critique of 'targeting'. We then examine the implications of our analysis for operations managers and the OM discipline.

\subsection{Can government intervention change things?}

Through the measures outlined here, the UK industrial strategy seeks to change the institutional architecture of UK industry, and hence provide the basis for the improved competitiveness of UK manufacturing firms. Hayes and Wheelwright's analysis drew attention to the (then) admirable characteristics of German and Japanese manufacturing, most of which can be explained in terms of capabilities rather than 'process choice'. Hayes and Wheelwright looked to these characteristics to inform how US manufacturing might be improved, but without accepting that these characteristics are, and can only be, a product of the institutional context in which manufacturing exists. In other words, box 4 of Figure 1 is dependent on, and a product of, many elements in boxes 1 and 2. In the case of contemporary Germany, Suzanne Berger draws attention to the:

"rich and diverse set of complementary capabilities in the industrial ecosystem: suppliers, trade associations, industrial collective research consortia, industrial research centers, Fraunhofer Institutes, university-industry collaborative, technical advisory committees. It's impossible to understand the different fates of manufacturing in the United States and Germany without comparing the density and richness of the resources available in the 
industrial ecosystem across much of Germany to the thin and shrinking resources available to U.S. manufacturers across much of our country" (Berger, 2013: 14)

Institutions, by definition, are enduring and often deeply embedded. As such, it could be argued that policies designed to alter them are working too much against the grain to succeed. It has indeed also been shown that significant national differences in management style, form and performance persist (Bloom and Van Reenen, 2010). However, work within the varieties of capitalism literature (Hall and Soskice, 2001), shows not only that countries vary in their institutional architectures, but that their architectures can and do change (Crafts and Hughes, 2013). We have also described in some depth the fundamental changes in policy stance and the switch between public and private sector activity that have occurred over the past two decades in the UK. Furthermore, as Herrigel (2010) has argued in the context of manufacturing, while actors in an economy certainly work within a set of existing institutional structures, they are also active, in the sense that they take creative action to change these institutions. "Identities and interests are not pre-given. They emerge jointly out of collective interactions about how to understand, define and resolve challenges posed in a common environment....action is a vital and social process. It is not something initiated by an atomized individual agent with pre-given preferences making discrete choices" (Herrigel, 2010: 7). This has strong parallels with Rodrik's view of industrial policy as a process of discovery (Hausmann and Rodrik, 2003), whereby, in a chronically uncertain environment, the understandings of industry, government and academic constituencies co-evolve.

It is rather early to tell whether the schemes recently introduced in the UK have brought about widespread and enduring changes in the institutional architecture of the industries we consider. But both the varieties of capitalism literature and Herrigel's analysis suggest that this is possible; and the fact that AeroCo now conducts over half of their manufacturing R\&D in collectively run research centers outside the firm is evidence that practices on the ground have changed. AeroCo's evolution illustrates how agents learn to work within and adjust the institutional architecture. This process of discovery illustrates the 'joint creative action' described by Herrigel. In AeroCo's case, it has taken ten years to reach this point. 


\subsection{Targeting in the UK industrial policy}

The UK example shows a clear shift toward targeting, most obviously by sector, but also by technology. This is combined with some mainly horizontal policies (e.g. skills development). Our research shows that the sectors and/or technologies chosen are those where there is already strength, and where improvements are likely to lead to more widespread benefits: as one of our BIS interviewees put it, this is not a policy to "prop up failing companies or industries". At the detailed level, e.g. in individual Catapults, targeting is a collective process. It is not a process of civil servants deciding exactly which projects and companies to support, but a process of critical peer review among industry, government and academic communities, within the institutional structure that has been defined i.e. Catapult Boards, different levels of membership and the rights they confer, and the threeway split of funding. Technology roadmapping and the determination of core Catapult projects are also collective activities. Berger (2013) describes such arrangements as creating 'club goods' based on membership rights. The collective knowledge and capabilities are therefore not all, as Marshall (1890) famously put it, 'in the air', but are embedded in particular buildings, practices and networks of people, and contained by specific systems of property rights. There are nevertheless also positive spillover effects: new relationships are established that provide benefits outside the confines of the Catapult projects, and capabilities are built among various agents - firms, government, the Catapults, the wider academic sphere - that can be drawn upon later. But this is not left entirely to chance.

Industrial policy is thus targeted in a broad sense, but it is the firms who decide whether to participate and precisely what to invest time and money in. A large part of industrial policy is then, as Kuznetsov and Sabel (2011) suggest, about designing the processes for scrutiny and error detection, rather than 'picking winners'. Furthermore, through the various formal and less formal interactions - at sector councils, Catapult boards, and around the coffee-machine in a particular HVM Catapult center - we have the 'thicker bandwidth' that Rodrik (2008) suggests is necessary to generate the benefits of interaction, to redirect the trajectory of activity when necessary, and to guard against regulatory 
capture. Scrutiny of the Catapult scheme in general (Hauser, 2014) and of the performance of finergrained levels of activity (e.g. PACEC, 2011; WECD, 2015) also allow failures to be identified and terminated or corrected. Overall, this consultative, options-based approach, creating the possibilities for successful development, as well as the mechanisms for selection and retention only of those that meet commercial as well as policy objectives, has been described as 'choosing races and placing bets' (Hughes, 2012).

\subsection{Implications for operations management}

The foregoing analysis has implications of three kinds for OM, and we deal with each in turn, although they are closely inter-connected. First, the changing nature of manufacturing has direct consequences for the set of decisions and actions involving senior operations managers, regardless of industrial policy. Second, the industrial policy interventions in a particular country or region affect the decisions and actions that operations managers should take. Third, the process of industrial policy development and implementation, and the need for close partnership between industry, government and academe suggest roles for OM practitioners and scholars in that process. In other words, we are suggesting that, while the 'micro' aspects of Hayes and Wheelwright's matrix (Figure 1) will remain the core of $\mathrm{OM}$, there must be a greater engagement with at least some aspects of the 'macro' level, from an OM perspective: it is not just someone else's problem, or an external 'given'.

\subsubsection{Operations management in the 'industrial commons'}

If, as we suggest, operations management is increasingly taking place in an open socio-technical system, rather than a closed, rational system, then the discipline and its practitioners must change accordingly. Gary Pisano, who brought a capabilities perspective into manufacturing strategy research (Hayes and Pisano, 1996) has more recently discussed such an open-system view in terms of the 'industrial commons' (Pisano and Shih, 2009; 2012a; 2012b), the collective system of research and 
development (R\&D), engineering and production capabilities that provide the basis for future innovation in an economy. Similarly, Berger and colleagues (Berger, 2013; Locke and Wellhausen, 2014) refer to the 'industrial ecosystem'. Both argue that, while domestic production may not always be 'valuable, in and of itself' (Berger, 2013: 7) - and, indeed, sometimes should be offshored - in some cases, the connection and/or close spatial proximity between production and innovation activities provides the basis for future technological development, and should be maintained, despite the attraction of short-term cost savings that ostensibly arise from offshoring production. As Pisano and Shih put it, "Manufacturing and innovation share the same industrial commons" (Pisano and Shih, 2012a:13). Similarly, Ketokivi and Ali-Yrkkö (2009) argue that from the point of view of both the firm and policy makers it is a mistake to believe that economic activity can be simply 'unbundled' into functional activities, and show that the higher the degree of knowledge intensity involved in an industrial activity and the greater its product and process complexity, then the greater will the benefits of co-location be. This resonates with the emphasis, in our example, on high-value manufacturing rather than traditional SIC-based sectors. Berger proposes a selective approach to rebuilding the ecosystem, pointing to the role of various forms of organizations beyond the firm, such as our example from the UK, that bridge holes and make connections. Berger and colleagues identified several successful instances involving, for example, trade associations, research centers and community colleges, but also found that many are fortuitous and isolated. However, there are also more deliberate recent experiments, in which government plays an active role (Berger, 2013). In many ways, these views parallel our analysis based on systems of innovation.

These analyses suggest that $\mathrm{OM}$ has to consider a wider range of organizational forms than its basic building blocks of firms, markets and supply chains. The industrial commons or ecosystem is very different to Hayes and Wheelwright's conceptualization: a change from a world composed of firms owning factories, within whose walls manufacturing capacity and resources were contained, to a world of inter-connected, varied and porous entities, developing, drawing on and capturing value from a combination of proprietary and collective assets, including capabilities and know-how within and beyond the firm, to which the manufacturing firm has access. In OM, a more inclusive perspective is 
already becoming evident in sustainability research, with Pagell and Wu (2009) arguing that we should 'reconfigure the supply chain' to incorporate such non-firm agents as NGOs. Horizontal collaborative relationships, such as those in the Catapults, also call into question the dictum that 'supply chains compete with supply chains' (Christopher, 2011): at some stages of the commercialization process, and on very specific parameters, this is true, but under other circumstances, precisely the opposite turns out to be the case.

Operations also require strategies and people that can understand the implications of their specific product and process technologies for linkages upstream with product development and R\&D and, downstream, with customers' context of use of products and associated services (Lay et al., 2010; Baines et al., 2009). However value is captured, it depends on a 'kernel' of technological and manufacturing know-how, which shapes how the linkages can be exploited. This is important not only for macro vertical integration and location decisions, as discussed by Berger and by Pisano and Shi, but also within firms in relation to job design and the development of skills - in technology, OM and 'shop-floor' roles. Jobs at low-, medium- and high-education levels all increasingly require interaction with colleagues (Kemeny and Rigby, 2012); IBM are seeking to develop 'T-shaped professionals', who complement depth of specialist expertise with the skills to interact effectively with those in other disciplines (Estrin, 2009); others have examined the importance of capabilities in inter-firm 'orchestration' (Parker and Anderson, 2002; Hagel and Brown, 2005; Spring and Araujo, 2014). Moreover, at firm level, recent operations strategy research (Su et al., 2014; Vanpoucke et al., 2014) is increasingly using a dynamic capabilities perspective, also emphasizing the shift from simply choosing and owning the right resources to being able to develop and access new capabilities and networks. Recent OM studies have begun to explore some aspects of this through the lens of 'culture' (Naor et al., 2010); we suggest that this can usefully be complemented by a more institutional perspective, since this is, in the medium-term, more susceptible to policy interventions.

\subsubsection{Operations management as a 'consumer' of industrial policy}


Industrial policy, if effective, should change the system of which operations are a part. As such, operations managers must understand how changes brought about due to industrial policy, intended to mitigate what we have termed systems failures, may change the managerial decisions and actions they might take. Simple policy measures might change the costs of a particular factor of production, e.g. land prices in a particular locality. These would be part of the 'local conditions' informing a typical OM facility location decision. Such analysis, however, would be unable to take account of the benefits of being part of an effectively-functioning system of innovation, a significant part of which is the presence of intermediate organizations, such as Catapults in the UK. It might be possible to attach financial value to some aspects: for example, Catapults often allow shared ownership of equipment, facilities and staff with other firms and with universities, hence reducing the fixed costs of establishing an operation. But most of the benefits arise from the innovative potential that exists in the interactions with other firms, universities, and policy makers, as evidenced by our industrial interviewees. Such benefits are notoriously difficult to quantify, of course, but then that is in the nature of strategic decisions. That is not to say that some up-front assessment of the basic ingredients is not possible, and this might take a contingency view. For example, an operation focusing on heavily service-enriched, engineer-to-order products is likely to value a geographical and institutional architecture that promotes close engagement with relevant customer sectors; an operation rooted in more fundamental technological innovation would be looking for the basic building blocks of relevant university departments, intermediate technology organizations and an institutional architecture that facilitated bridging the gap between R\&D and commercialization.

Operations managers must also understand and take advantage of 'ecosystem' connections facilitated by industrial policy. They must find a balance between focusing on their own operations and immediate supply chains, and on the wider activities of maintaining and developing the extended ecosystem, often in conjunction with policy and intermediate organizations. Our examples demonstrate that, for the operations manager, industrial policy is not something 'out there', beyond the remit of the daily, weekly and monthly set of operations activities, but is very much present, in the 
concrete form of intermediate organizations and other initiatives of this type, which are embodiments of, and platforms for, the industrial commons.

\subsubsection{Operations Management and industrial policy processes}

We have argued that the technological and sectoral-systems approaches call for a fine-grained analysis of value chains, and a process of discovery among the industrial, academic and policy constituencies. OM needs to be represented among at least the first two of these constituencies. Bridging innovation gaps with the help of intermediate organizations requires knowledge of specific technologies, but also an understanding of more central OM issues such as scale-up, production process design and cost structures. In other words, operations managers, as well as technologists, need to participate in such projects, and in the wider process of industrial policy development. For example, AeroCo's project manager for Catapult projects is a former plant manager, and so can represent the OM view in, say, making sure that new process technologies are 100\% (not 95\%) proven out before being introduced into production plants that are expected to delivery dependable quality and adherence to production schedules. This has the reinforcing effect that plant managers have increasing confidence in the work carried out in the Centres, and have come to see them as natural extensions of their own capacities and capabilities, rather than as remote 'boffins' who are likely to deliver incomplete and disruptive 'solutions'.

There is also an OM role in the second constituency - the academic one. As innovation policy converges with industrial policy, science and engineering scholars naturally play an important role. But OM scholars need to have a voice as well. As we have taught for many years, operations should not be on the receiving end of an 'over-the-wall' product development process; as such, it is important for OM scholars to be involved in the projects and programs underpinned by industrial policy. This would not only ensure that OM thinking pervades, from the outset, the link between technology, production and service stages of the value-chain, but will also allow OM to update itself as it adapts its principles to new domains such as biotechnology, sustainable energy, or smart cities. Perhaps OM 
experts will have roles as policymakers, too. The recent 'Future of Manufacturing' study by the UK Government (Foresight, 2013) did invite contributions from OM scholars. But whether we can look forward to the Departments in our respective governments being staffed by OM experts as well as economists is another matter. We can but hope.

\section{Conclusion}

Our analysis suggests that, as Rosenfield has argued, industrial policy can help provide a context in which manufacturing firms can be competitive in high-cost economies. The central issue is innovation: manufacturing depends on it to create value, and industrial policy must increasingly encompass innovation policy. Seen from a systems-of-innovation perspective, the role of industrial policy is to overcome systems failures, facilitate interaction and cooperation between firms and other agents in the system, and incentivize innovative behavior. Effective, innovation-based 'ecosystems' create the setting in which manufacturing firms can be competitive - not necessarily by carrying out production tasks, but by creating value from the unique and valuable capabilities that arise from connecting their distinctive manufacturing technological core to the capabilities of other agents in the system.

OM must adapt its conceptual toolkit so as to incorporate and theorize networks wider in scope and more fluid than the firms, supply chains and markets with which it is familiar. It must also understand more fully what the implications of such a world are for the jobs, skills and roles of people working in operations. Senior operations managers must learn how to take account of and benefit from the opportunities afforded by an active industrial policy. Finally, OM practitioners and academics alike must play their part in the creation and development of industrial policy, so that OM concerns and principles are incorporated alongside those of technologists and economists.

This intersection of OM and industrial policy suggests a rich research agenda. We have begun to show what an innovation-centered, extended operation looks like and how intermediate research organizations can help it to work. But there is a great deal more to reveal about the practices, 
institutional arrangements and operations roles of such collective endeavors. Furthermore, in the relatively limited international operations literature, there is an opportunity to develop much greater understanding of how the institutional architecture and industrial policy of different countries affect and are affected by manufacturing location decisions: this would complement recent studies using the lens of 'culture'. Finally, there is a big job to do in raising the level of engagement of OM practitioners and scholars in the industrial-policy development process itself, particularly as industrial policy becomes more active and targeted, and increasingly directed at the detailed level - the competitiveness of firms and their operations.

\section{$\underline{\text { References }}$}

Abernathy, W.J., Clark, K.B. and Kantrow, A.M. (1981) The new industrial competition. Harvard Business Review, 59, 5, 68-81.

AMPSC (2012) Report to the President on capturing domestic comparative advantage in advanced manufacturing, President's Council of Advisors on Science and Technology, Executive Office of the President of the United States July

Anderson, J.C., Cleveland, G. and Schroeder, R.G. (1989) Operations strategy: a literature review. Journal of Operations Management, 8, 2, 133-158.

Baines, T., Lightfoot, H., Peppard, J., Johnson, M., Tiwari, A., Shehab, E. and Swink, M. (2009) Towards an operations strategy for product-centric servitization. International Journal of Operations \& Production Management, 29, 5, 494-519.

Baldwin, R.E. and Evenett, S. (2015) Value creation and trade in 21st century manufacturing. Journal of Regional Science, 55, 1, 31-50.

Baldwin, R.E. and Evenett, S.J. (2012) Value creation and trade in 21st century manufacturing: what policies for UK manufacturing? IN Greenaway, D. (Ed.) The UK in a global world: how can the UK focus on steps in global value chains that really add value? London, Centre for Economic Policy Research 71-128

Barney, J.B. (1991) Firm resources and sustained competitive advantage. Journal of Management, $17,99-120$.

Berger, S. (2013) Making in America: from innovation to market, Cambridge, MA, MIT Press.

BIS (2010) BIS Economics Paper No.7: Understanding local growth, Department for Business, Innovation and Skills,

BIS (2011) Innovation and research strategy for growth, Department for Business, Innovation and Skills, 
BIS (2012) BIS Economic paper No.18 - Industrial strategy: UK sector analysis, Department for Business, Innovation and Skills, September 2012

Bleda, M. and Del Rio, P. (2013) The market failure and the systemic failure rationales in technological innovation systems. Research Policy, 42, 5, 1039-1052.

Blinder, A.S. (2006) Offshoring: the next industrial revolution? Foreign Affairs, 85, 2, 113-128.

Bloom, N. and Van Reenen, J. (2010) Why do management practices differ across firms and countries? The Journal of Economic Perspectives, 24, 1, 203-224.

Bohn, R.E. (2005) From art to science in manufacturing: The evolution of technological knowledge. Foundations and Trends in Technology, Information and Operations Management, 1, 2, 182.

Bower, J., Bartlett, C., Christensen, C.R., Pearson, A.E. and Andrews, K. (1991) Business policy, Homewood IL, Irwin.

Bower, J.L. (1982) Business policy in the 1980s. Academy of Management Review, 7, 4, 630-638.

Buhman, C., Kekre, S. and Singhal, J. (2005) Interdisciplinary and interorganizational research: establishing the science of enterprise networks. Production and Operations Management, 14, 493-513.

Buigues, P.-A. and Sekkat, K. (2011) Public subsidies to business: an international comparison. Journal of Industry, Competition and Trade, 11, 1, 1-24.

Carlsson, B. and Jacobsson, S. (1997) Diversity creation and technological systems: a technology policy perspective. IN Edquist, C. (Ed.) Systems of innovation: Technologies, institutions and organizations. London, Pinter. 266-294

Carter, C.R. and Easton, P.L. (2011) Sustainable supply chain management: evolution and future directions. International Journal of Physical Distribution \& Logistics Management, 41, 1, 46-62.

Chang, H.-J., Andreoni, A. and Kuan, M.L. (2013) International industrial policy experiences and the lessons for the UK. Centre for Business Research, University of Cambridge, Working paper no. 450 .

Choi, T.Y., Dooley, K.J. and Rungtusanatham (2001) Supply networks and complex adaptive systems: control versus emergence. Journal of Operations Management, 19, 3, 351-366.

Christopher, M. (2011) Logistics and supply chain management, Pearson Education UK.

Clark, K.B. (1996) Competing through manufacturing and the new manufacturing paradigm: is manufacturing strategy passé? Production and Operations Management, 5, 1, 42-58.

Crafts, N. and Hughes, A. (2013) Industrial policy for the medium to long-term, Foresight Future of Manufacturing Project, Evidence Paper 37. London, Government Office for Science.

DBERR (2009) New industry, new jobs, Department for Business, Enterprise and Regulatory Reform,

Delgado, M., Ketels, C.H., Porter, M.E. and Stern, S. (2012) The determinants of national competitiveness, NBER Working Paper No 18249, 
DIUS (2008) Innovation nation, Department for Innovation, Universities and Skills,

Dodgson, M., Hughes, A., Foster, J. and Metcalfe, S. (2011) Systems thinking, market failure, and the development of innovation policy: The case of Australia. Research Policy, 40, 9, 1145-1156.

DTI (1988) DTI - the department for enterprise. Department of Trade and Industry White Paper Cm 278. London, HMSO.

DTI (1995) Competitiveness: forging ahead. Department of Trade and Industry White Paper Cm 2867. London, HMSO.

DTI (1996) Competitiveness: creating the enterprise centre of Europe. Department of Trade and Industry White Paper Cm 3300. London, HMSO.

DTI (1998) Our competitive future: building the knowledge driven economy. Department of Trade and Industry White Paper Cm 4176. London, HMSO.

DTI (2003a) Competing in the global economy - the innovation challenge', DTI Economics Paper No. 7, DTI,

DTI (2003b) UK competitiveness: moving to the next stage - a report by Professor Michael E Porter and Christian H.M. Ketels, DTI Economics Paper No. 3, DTI and ESRC,

Edquist, C. (Ed.) (1997) Systems of innovation: technologies, institutions, and organizations, London, Pinter.

Edquist, C. and Johnson, B. (1997) Institutions and organizations in systems of innovation. IN Edquist, C. (Ed.) Systems of innovation: technologies, institutions and organizations. London, Pinter. 41-63

Estrin, J. (2009) Closing the innovation gap, San Francisco, McGraw-Hill.

Ettlie, J.E. (1995) Product-process development integration in manufacturing. Management Science, $41,7,1224-1237$.

Ferdows, K. (1997) Made in the world: the global spread of production. Production and Operations Management, 6, 2, 102-109.

Fisher, M. (1997) What is the right supply chain for your product? Harvard Business Review, MarchApril, 105-116.

Foreman-Peck, J. and Federico, G. (Eds.) (1999) European industrial policy: the twentieth-century experience, Oxford, Oxford University Press.

Foresight (2013) The future of manufacturing: A new era of opportunity and challenge for the UK, The Government Office for Science,

Frohlich, M.T. and Westbrook, R. (2001) Arcs of integration: an international study of supply chain strategies. Journal of Operations Management, 19, 2, 185-200.

Fuchs, E. and Kirchain, R. (2010) Design for location? The impact of manufacturing offshore on technology competitiveness in the optoelectronics industry. Management Science, 56, 12, 2323-2349.

Greenaway, D. (Ed.) (2012) The UK in a Global World - How can the UK focus on steps in global value chains that really add value? , London, Centre for Economic Policy Research (CEPR). 
Guide, V.D.R. and Van Wassenhove, L.N. (2006) Closed-loop supply chains: an introduction to the feature issue (Part 1). Production and Operations Management, 15, 3, 345-350.

Guthrie, J. (2004) Why ditching the DTI would be bad for business, Financial Times http://www.ft.com/cms/s/0/f545647a-c96a-11d8-b1a8-00000e2511c8.html\#axzz3Rv7HiDPT, 6th April 2015

Hagel, J. and Brown, J.S. (2005) The only sustainable edge : why business strategy depends on productive friction and dynamic specialization, Boston, Mass., Harvard Business School Press.

Hall, P.A. and Gingerich, D.W. (2009) Varieties of capitalism and institutional complementarities in the political economy: An empirical analysis. British Journal of Political Science, 39, 03, 449-482.

Hall, P.A. and Soskice, D. (Eds.) (2001) Varieties of capitalism: The institutional foundations of comparative advantage, Oxford, Oxford University Press.

Harrison, A. and Mcmillan, M. (2010) Offshoring jobs? Multinationals and U.S. manufacturing employment. Review of Economics and Statistics, 93, 3, 857-875.

Hauser, H. (2010) The current and future role of technology and innovation centres in the UK, Secretary of State, Department for Business Innovation \& Skills,

Hauser, H. (2014) Review of the Catapult network: recommendations on the future shape, scope and ambition of the programme, Department for Business, Innovation and Skills,

Hausmann, R. and Rodrik, D. (2003) Economic development as self-discovery. Journal of Development Economics, 72, 2, 603-633.

Hayes, R., Wheelwright, S. and Clark, K. (1988) Dynamic manufacturing: creating the learning organization, Free Press, New York.

Hayes, R.H. (1992) Production and operations management's new "requisite variety". Production and Operations Management, 1, 3, 249-253.

Hayes, R.H. (2008) Operations management's next source of galvanizing energy? Production and Operations Management, 17, 6, 567-572.

Hayes, R.H. and Pisano, G.P. (1994) Beyond world-class: the new manufacturing strategy. Harvard Business Review, Jan-Feb, 77-86.

Hayes, R.H. and Pisano, G.P. (1996) Manufacturing strategy: at the intersection of two paradigm shifts. Production and Operations Management, 5, 1, 25-41.

Hayes, R.H. and Schmenner, R.W. (1978) How should you organise manufacturing? Harvard Business Review, Jan-Feb, 105-118.

Hayes, R.H. and Wheelwright, S.C. (1979a) The dynamics of product-process life-cycles. Harvard Business Review, Mar-Apr, 127-136.

Hayes, R.H. and Wheelwright, S.C. (1979b) Link manufacturing process and product life-cycles. Harvard Business Review, Jan-Feb, 133-140.

Hayes, R.H. and Wheelwright, S.C. (1984) Restoring our competitive edge: competing through manufacturing, New York, John Wiley. 
Herrigel, G. (2010) Manufacturing possibilities: Creative action and industrial recomposition in the United States, Germany, and Japan, Oxford, Oxford University Press.

HM Treasury (2003) The Lambert review of business-university collaboration, H.M Treasury,

HM Treasury (2004) Science and innovation investment framework 2004-2014, H.M. Treasury,

Hughes, A. (2008) Innovation policy as cargo cult: myth and reality in knowledge-led productivity growth. IN Bessant, J. \& Venables, T. (Eds.) Creating wealth from knowledge: Meeting the innovation challenge. Cheltenham, Edward Elgar. 80-104

Hughes, A. (2010) Entrepreneurship and innovation policy: retrospect and prospect. IN Uberoi, V., Coutts, A., Halpern, D. \& Mclean, I. (Eds.) Options for Britain II: cross-cutting policy issues - changes and challenges. Chichester, John Wiley and Sons.

Hughes, A. (2012) Choosing races and placing bets: UK national innovation policy and the globalisation of innovation systems. IN Greenaway, D. (Ed.) The UK in a global world How can the UK focus on steps in global value chains that really add value? London, Centre for Economic Policy Research (CEPR). 37-70

Hughes, A. (2015) Review of approaches to the commercialisation of university research and support for university industry collaboration in the UK. Report for Securing Australia's Future, Australian Council of Learned Academies, www.acola.org.au.,

Iversen, T. and Soskice, D. (2010) Real exchange rates and competitiveness: The political economy of skill formation, wage compression, and electoral systems. American Political Science Review, 104, 03, 601-623.

Kemeny, T. and Rigby, D. (2012) Trading away what kind of jobs? Globalization, trade and tasks in the US economy. Review of World Economics, 148, 1, 1-16.

Ketokivi, M. and Ali-Yrkkö, J. (2009) Unbundling R\&D and manufacturing: postindustrial myth or economic reality? Review of Policy Research, 26, 1-2, 35-54.

Klein Woolthuis, R., Lankhuizen, M. and Gilsing, V. (2005) A system failure framework for innovation policy design. Technovation, 25, 6, 609-619.

Krugman, P. (1994) Competitiveness: a dangerous obsession. Foreign Affairs, 73, 2, 28-44.

Kuznetsov, Y. and Sabel, C. (2011) New open economy industrial policy: making choices without picking winners. PREM Notes No. 161. World Bank.

Lamming, R. (1993) Beyond partnership: strategies for innovation and lean supply, Hemel Hempstead, Prentice-Hall.

Lay, G., Copani, G., Jäger, A. and Biege, S. (2010) The relevance of service in European manufacturing industries. Journal of Service Management, 21, 715-726.

Locke, R.M. and Wellhausen, R.L. (Eds.) (2014) Production in the innovation economy, Cambridge MA, MIT Press.

Malerba, F. (2004) Sectoral systems of innovation: basic concepts. Sectoral systems of innovation: concepts, issues and analyses of six major sectors in Europe. Cambridge, Cambridge University Press. 9-41

Marshall, A. (1890) Principles of economics, London, Macmillan. 
Menor, L.J., Kristal, M.M. and Rosenzweig, E.D. (2007) Examining the influence of operational intellectual capital on capabilities and performance. Manufacturing Service Operations Management, 9, 4, 559-578.

Miles, R.E., Snow, C.C., Fjeldstad, Ø.D., Miles, G. and Lettl, C. (2010) Designing organizations to meet 21 st-century opportunities and challenges. Organizational Dynamics, 39, 2, 93-103.

Mills, J., Platts, K. and Bourne, M. (2003) Applying resource-based theory: methods, outcomes and utility for managers. International Journal of Operations and Production Management, 23, 2, 148-166.

Mina, A., Connell, D. and Hughes, A. (2009) Models of technology development in intermediate research organisations. CBR Working Paper 396. Centre for Business Research, University of Cambridge.

Naor, M., Linderman, K. and Schroeder, R. (2010) The globalization of operations in Eastern and Western countries: unpacking the relationship between national and organizational culture and its impact on manufacturing performance. Journal of Operations Management, 28, 3, 194-205.

Neely, A. (2008) Exploring the financial consequences of the servitization of manufacturing Operations Management Research, 1, 2, 103-118.

North, D.C. (1990) Institutions, institutional change and economic performance, Cambridge, CUP.

O'Sullivan, E., Andreoni, A., López-Gómez, C. and Gregory, M. (2013) What is new in the new industrial policy? A manufacturing systems perspective. Oxford Review of Economic Policy, $29,2,432-462$.

OECD (2007) Staying competitive in the global economy: moving up the value chain, OECD Publishing,

Oliva, R. and Kallenberg, R. (2003) Managing the transition from products to services. International Journal of Service Industry Management, 14, 2, 160-172.

Oxford Economics (2008) Study of the impact of the intermediate research and technology sector on the UK economy. Oxford, Oxford Economics.

PACEC (2011) Technology Strategy Board: Evaluation of the collaborative research and development programmmes, $\mathrm{PACEC}$,

Pagell, M. and Wu, Z. (2009) Building a more complete theory of sustainable supply chain management using case studies of 10 exemplars. Journal of Supply Chain Management, 45, 2, 37-56.

Parker, G.G. and Anderson, E.G. (2002) From buyer to integrator: The transformation of the supplychain manager in the vertically disintegrating firm. Production and Operations Management, 11, 1, 75-91.

Pilkington, A. and Meredith, J.R. (2008) The evolution of the intellectual structure of operations management-1980-2006: A citation/co-citation analysis. Journal of Operations Management, 27, 3, 185-202.

Pisano, G. and Shih, W. (2012a) Producing prosperity: why America needs a manufacturing renaissance, Harvard Business Review Press. 
Pisano, G.P. and Shih, W.C. (2009) Restoring American competitiveness. Harvard Business Review, $87,7-8,114-125$.

Pisano, G.P. and Shih, W.C. (2012b) Does America really need manufacturing? Harvard Business Review, 90, 3, 94-102.

Ponomarov, S.Y. and Holcomb, M.C. (2009) Understanding the concept of supply chain resilience. The International Journal of Logistics Management, 20, 1, 124-143.

Porter, M.E. (1980) Competitive strategy, New York, Free Press.

Porter, M.E. (1990) The competitive advantage of nations, Basingstoke, Macmillan.

Prahalad, C.K. and Hamel, G. (1990) The core competence of the corporation. Harvard Business Review, May-Jun, 79-91.

Rodrik, D. (2008) Normalizing industrial policy, International Bank for Reconstruction and Development/The World Bank.

Rosenfield, D.B. (2014) Innovation and onshoring: the case for product variety. IN Locke, R. M. \& Wellhausen, R. L. (Eds.) Production in the innovation economy. Cambridge MA, MIT Press. 211-233

Shi, Y. and Gregory, M. (1998) International manufacturing networks - to develop global competitive capabilities. Journal of Operations Management, 16, 2â€“3, 195-214.

Sinha, K.K. and Van De Ven, A.H. (2005) Designing work within and between organizations. Organization Science, 16, 4, 389-408.

Skinner, W. (1969) Manufacturing - missing link in corporate strategy. Harvard Business Review, May-Jun, 136-145.

Skinner, W. (1974) The focussed factory. Harvard Business Review, May-Jun, 113-121.

Skinner, W. and Rogers, D.C.D. (1968) Manufacturing policy in the plastcis industry: a casebook of major production problems, Homewood IL, Irwin.

Slack, N. (1987) The flexibility of manufacturing systems. International Journal of Operations and Production Management, 7, 4, 35-45.

Spring, M. and Araujo, L. (2014) Indirect capabilities and complex performance: Implications for procurement and operations strategy. International Journal of Operations \& Production Management, 34, 2, 150-173.

Stalk, G. (1988) Time: the next source of competitive advantage. Harvard Business Review, Jul-Aug, 41-48.

Su, H.-C., Linderman, K., Schroeder, R.G. and Van De Ven, A.H. (2014) A comparative case study of sustaining quality as a competitive advantage. Journal of Operations Management, 32, 7, 429-445.

TSB (2011) Technology and innovation centres - closing the gap between concept and commercialisation, Technology Strategy Board,

TSB (2012) High Value Manufacturing Strategy 2012-2015, Technology Strategy Board, 
Ulrich, K.T. and Eppinger, S.D. (1992) Product Development. Design Management Journal, , 47-54.

UNCTAD (2013) World Investment Report 2013 - Global value chains: investment for trade and development, United Nations,

Vanpoucke, E., Vereecke, A. and Wetzels, M. (2014) Developing supplier integration capabilities for sustainable competitive advantage: A dynamic capabilities approach. Journal of Operations Management, 32, 7, 446-461.

Voss, C.A. (1995) Alternative paradigms for manufacturing strategy. International Journal of Operations and Production Management, 15, 4, 5-16.

Voss, C.A. (2005) Paradigms of manufacturing strategy re-visited. International Journal of Operations \& Production Management, 25, 12, 1223-1227.

Warwick, K. (2013) Beyond industrial policy: emerging issues and new trends Science, Technology and Industry Policy Papers, No.2. OECD

WECD (2015) High Value Manufacturing Catapult: pathways to impact, Warwick Economics \& Development,

Wessner, C.W. and Wolff, A.W. (2012) Rising to the challenge: US innovation policy for the global economy, The National Academies Press,

Wheelwright, S.C. and Clark, K.B. (1992) Revolutionizing product development: quantum leaps in speed, efficiency and quality, New York, NY, Free Press.

Willetts, D. (2013) Eight great technologies, Department for Business, Innovation and Skills https://www.gov.uk/government/speeches/eight-great-technologies, 8th April 2015

Wise, R. and Baumgartner, P. (1999) Go downstream - The new profit imperative in manufacturing. Harvard Business Review, 77, 5, 133-141.

Womack, J.P., Jones, D.T. and Roos, D. (1990) The machine that changed the world, New York, Rawson Associates.

World Bank (2014) Doing business 2015: going beyond efficiency. Washington DC, The World Bank.

World Economic Forum (2015) Global competitiveness report 2014-15, World Economic Forum,

Zhang, Y. and Gregory, M. (2011) Managing global network operations along the engineering value chain. International Journal of Operations \& Production Management, 31, 7, 736-764.

Zsidisin, G.A. (2003) Managerial perceptions of supply risk. Journal of Supply Chain Management, 39, 4, 14-26. 


\section{Appendix: Some distinctive features of the UK Economy}

The UK economy has some distinctive features that need to be taken into account when attempting to translate insights to other developed economies, and these are now summarized. (Data in this section are all taken from Foresight (2013)). UK economic growth and productivity performance in manufacturing has been relatively weak by international standards. From 1980 to 2010, UK manufacturing output grew on average at $0.5 \%$ per annum, compared to around $2.5 \%$ in the USA and $2.3 \%$ in Japan. This relatively modest output growth was, moreover, achieved primarily by costcutting efficiency gains. In contrast in the USA, productivity growth was accompanied by significant investment in fixed capital, which did not occur in the UK. UK manufacturing employment has declined significantly. In the long run, it fell from around 9,000,000 people in 1966 to fewer than $3,000,000$ in 2011 . The share of manufacturing in value added also declined more rapidly than in other developed economies, from around 30\% in the early 1970s to around 10\% in 2011. This pattern is similar to that experienced in France and the USA but is more pronounced. Over this period, the UK trade balance deteriorated significantly, so that by 2011 there was a trade deficit of $-4.1 \%$ of GDP. The UK also has a relatively weak innovation performance by international standards. For example, in 2008 around $13 \%$ of UK manufacturing turnover was attributable to products that were new to the market, which was around half the figure for Germany. A similar pattern emerges when other indicators of innovation, such as patents, trademarks and industrial design rights are considered. The relatively weak innovation performance of the UK economy and of UK manufacturing is associated with a relatively low and declining commitment to capital expenditure, and in particular R\&D.

In addition to having a relatively low commitment to spending on $\mathrm{R} \& \mathrm{D}$ compared to all its major competitors, the UK is also an extreme outlier in terms of the internationalisation of its R\&D effort. The proportion of R\&D in UK manufacturing and services which is funded from overseas is twice as high as the nearest major industrial economy and is five times as high as in Germany. Moreover, in addition to having a very high proportion of investment expenditure funded from overseas, the actual conduct of R\&D expenditure in the UK is dominated by foreign-owned firms. For example, in 2008, 
spending on manufacturing $\mathrm{R} \& \mathrm{D}$ was higher in foreign-owned firms than in UK-owned firms. In addition, for the UK-owned firms $42 \%$ of the funding was from sources outside the UK. This particular feature of the UK economy means that policy is particularly concerned with issues of location and the ability to attract and maintain relatively footloose multi-national R\&D and to convert $R \& D$ carried out in the UK into value added in the home economy.

The extreme concentration of the UK private sector R\&D effort in a few hands (the largest $10 \mathrm{R} \& \mathrm{D}$ performers in the UK account for over a third of all manufacturing R\&D) is coupled with a similar high level of concentration of the public sector R\&D effort in the higher education sector. There, the top ten research universities account for around three quarters of all publicly-funded research. The fact that the UK higher education sector is, however, outstanding in terms of international performance measured both in terms of citation totals and in citation productivity per head in the academic community has meant that policy has been particularly concerned with enhancing the extent to which such academic excellence may be translated into higher productivity and innovative performance. This has led to a considerable emphasis in policy intended to increase universityindustry collaboration. A recent example of this is the Catapult Programme, which is discussed in the paper. 